\title{
GYÓGYPEDAGÓGIA A LOVAGLÁSBAN, AVAGY A LOVAGLÁS A GYÓGYPEDAGÓGIÁBAN
}

\section{SPECIAL EDUCATION IN HORSE RIDING, OR HORSE RIDING IN SPECIAL EDUCATION}

\author{
Koltai Blanka Sára ${ }^{1 *}$, Dr. Devosa Iván Ph.D. ${ }^{2}$, Dr. Tiszai Luca, Ph.D. ${ }^{1}$ \\ 1 Juhász Gyula Pedagógusképző Kar, Szegedi Tudományegyetem, Magyarország \\ 2 Pedagógusképző Kar, Neumann János Egyetem, Magyarország \\ https://doi.org/10.47833/2020.1.ART.001
}

\section{Kulcsszavak: \\ gyógypedagógia \\ lovaglás \\ testtartás \\ idegrendszer \\ egészségfejlesztés}

\section{Keywords:}

special education

horse riding

posture

nervous system

health promotion

\section{Cikktörténet:}

Beérkezett 2019. október 24.

Átdolgozva 2020. február 3

Elfogadva 2020. február 20.

\begin{abstract}
Összefoglalás
A gyógylovaglás és ezen belül is a lovasterápia egyre elterjedtebb Magyarországon. A gyógylovaglás 2 fő ágazata a lovasterápia és a parasport, melyböl minket a lovasterápia fejlesztő hatása érdekelt elsődlegesen. A fejlesztő munka alapja a ló társasága és mozgása, és az abból adódó idegrendszeri stimulációk. Ebböl adódik a következő területek sikeres fejleszthetősége a foglalkozások során: egyensúlyérzékelés, koordináció, érzékelés, tartás, járás.
\end{abstract}

\begin{abstract}
Equestrian therapy and in particular equestrian riding is becoming more and more widespread in Hungary. The two main branches of equestrian riding are equestrian therapy and parasport, of which we are primarily interested in the developmental effect of equestrian therapy. The development work is based on the movement of the horse and the resulting stimulation of the nervous system. This results in the successful development of equestrian training in the following areas: balance, coordination, perception, posture, walking.
\end{abstract}

\section{Bevezetés}

Wipke C. Hartje 2012-ben megjelent Lovasterápia [1] címü könyvében, mely Magyarországon jelenleg az egyik legelterjedtebb lovasterápiás könyv, 4 esettanulmányról is olvashatunk melyek igazolják a lovasterápia eredményességét. $A z$ esettanulmányok olvasása során megbizonyosodhatunk arról, hogy a lovasterápia rendkívül sokszínủ és változatos, valamint, hogy a különböző ágai szoros kapcsolatban vannak egymással, mégis elkülönülnek. A vezető lovasterápiás országok között meg kell említeni az Amerikai Egyesült Államokat, Németországot, Ausztriát, Svájcot, illetve Angliát. A lovasterápia Magyarországon is egyre elterjedtebb. Az első magyar lovasterápiás szakember képző tanfolyamot 1997-ben rendezték meg a Hortobágyon angol szakemberek segítségével és a Nemzetközi Gyermekmentő Szolgálat (NGYSZ) megrendezésével, illetve az előzetes igények felmérése után. A képzés után alakult meg a Magyar Lovasterápiás Szövetség.

A gyógylovaglásban részt vevő személyeket a továbbiakban lovasként említem, lévén úgy gondolom a gyógylovaglás és annak ágazatainak az egyik legnagyobb előnye, hogy a fejlesztésre

\footnotetext{
* Kapcsolattartó szerző. Tel.: +36 204858506

E-mail cím: Blanka Koltai <koltai.blanka997@gmail.com>
} 
érkező személy nem érzi magát kívülállónak, mivel a terápiát úgy éli meg, hogy lovagolni érkezett. Továbbá nagy előnye ennek a fejlesztési módszernek, hogy a terápiákkal járó, a társadalom által kialakított negatív stigmákat könnyen levetkőzhetjük, hiszen a foglalkozás lovaglásként is funkcionál, nem csak fejlesztésként. (PI.: A fejlesztés végén a megfelelő személyek számára felajánlott jutalom ügetés stb.)

\section{A gyógylovaglás}

A gyógylovaglás olyan lóval kialakított foglalkozási forma, melynek célja, hogy a személyt a ló jelenléte inspirálja, segítse a fejlesztése során. A gyógylovaglás 2 fö ágazata a lovasterápia és a parasport. A parasport vagy akadályozottak sportlovaglása - sérültek, fogyatékkal élők szabadidős vagy verseny- sportja a lovas szakágaknak megfelelö́ (díjlovaglás, fogathajtás) színtereken. Olyan lovas oktató, lovas edző vezetésével tartjak, aki a speciális továbbképzést elvégezte [2,3]. A gyógylovaglás parasport ágazatáról most részletesebben nem értekezünk.

A gyógylovaglás Magyarországon 2 szakággal, azon belül a lovasterápia 3 területtel rendelkezik, melyet a probléma típusa, a szakember képzettsége, a kitüzött cél és a módszerek határoznak meg (1. ábra).

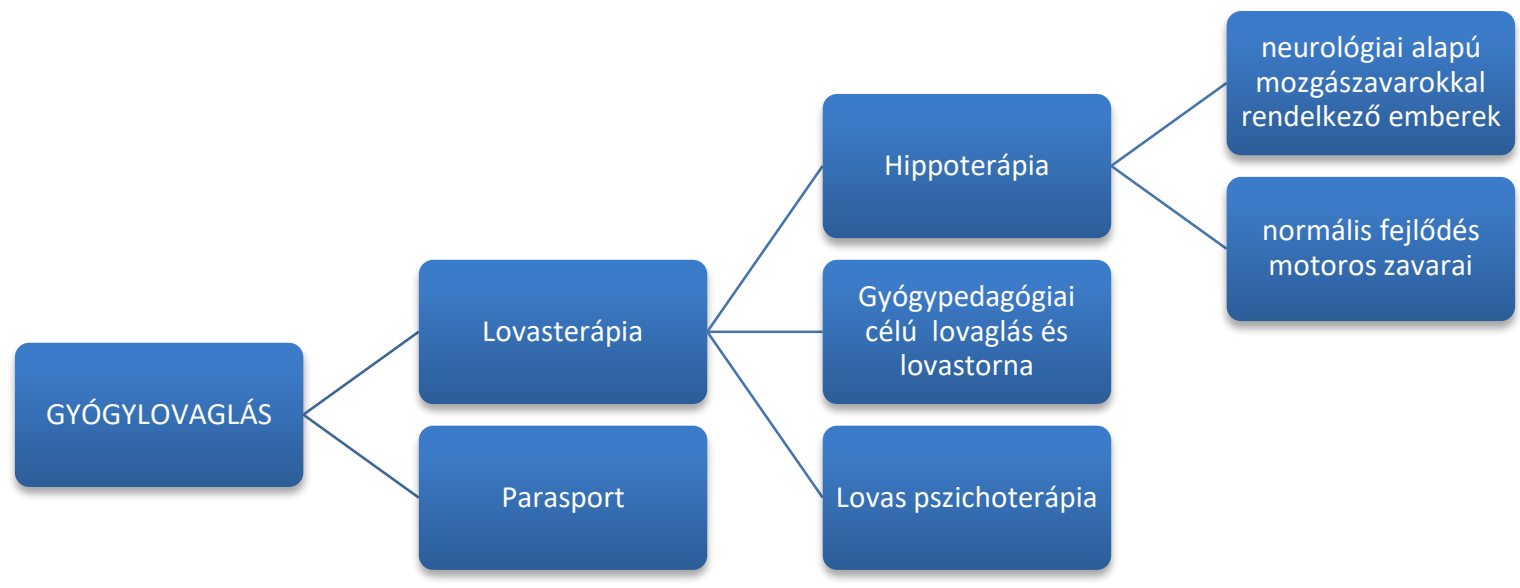

1. ábra: A Magyarországon megvalósuló gyógylovaglás 2 szakága és a lovasterápia 3 területe.

- Hippoterápia olyan orvosi indikáció alapján történő neurofiziológiai egyéni gyógytorna alapú kezelés, ahol a lépésben járó ló mozgásimpulzusait használjuk fel a lovas fejlesztése céljából. Hippoterapeuta végzettségű gyógytornász vagy szomatopedagógus végeztetheti $[2,4,5]$. $A$ hippoterápiának két csoportját különíthetjük el. A neurológiai mozgászavarok egyik csoportja a normális motoros fejlődés zavarai, ide tartoznak az agy születés elötti, illetve a születés utáni károsodásai. Az alkalmazási terület másik csoportja a lóháton végzett gyógytorna, melyet a már kifejlődött agy károsodása esetén alkalmaznak, a károsodás lehet idegrendszeri károsodások vagy a központi idegrendszer megbetegedései által kialakult problémák.

- „Gyógypedagógiai lovaglás és lovastorna - fejlesztő, nevelő célú egyéni vagy csoportos foglalkozás, melyet lovasterapeuta végzettségű gyógypedagógus vezet. Használhatják mindhárom jármódot, különböző eszközöket, játékokat, a lovaglás és a lovastorna elemeit, a terápiás cél függvényében. A gyógypedagógiai lovaglás és voltizsálás számos olyan elemet tartalmaz, amely lehetővé teszi a „lovasok” komplex fejlesztését egy olyan területen, ahol a ló nem eszköz, hanem egy aktív cselekvő társ" [3,4,5]. A voltizsálás latin eredetű magyarosított szó, melynek jelentése röpködni, ami a lovas tornát és a lovon végzett gimnasztikai gyakorlatokat jelöli. 
- Lovas pszichoterápia során az egyes pszichés kórképek kiegészítő kezelése a cél. A ló személyiségét, a lóval való foglalkozás pszichés hatásait használja terápiás céllal, pszichológus lovasterapeuta vezetésével [2]. A lovas pszichoterápia során az ember és állat közti lehetséges kapcsolat adja ennek az ágnak a gyógyító munka alapját (2. ábra), kiemelve a tiszteletet és a bizalmat: a ló segítségével a foglalkozások során a pszichés betegségekkel küzdök újra megérezhetik, hogy elfogadják őket, illetve azt, hogy szükség van rájuk.

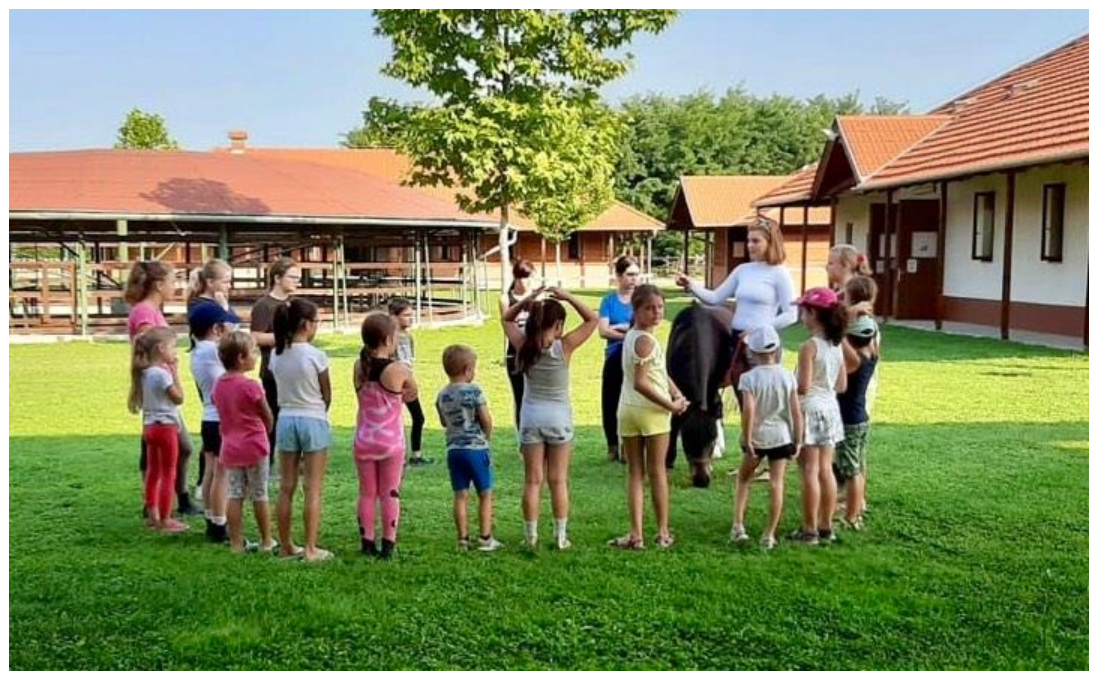

2. ábra Lóval történö csoportos ismerkedés.

A gyógylovaglás ágait az 1. táblázatban bemutatott szerint különálló egységekként értelmeztük, de fontos megemlíteni, hogy ezeknek az ágaknak különböző metszetei vannak. Minden értelmi fejlesztésnek alapja a mozgásfejlesztés.

1. táblázat: A lovasterápia 3 területe közötti különbségek Magyarországon.

\begin{tabular}{|c|c|c|c|}
\hline & Hippoterápia & $\begin{array}{l}\text { Gyógypedagógiai } \\
\text { lovaglás és } \\
\text { lovastorna }\end{array}$ & Lovas pszichoterápia \\
\hline $\begin{array}{l}\text { Szükséges } \\
\text { végzettség }\end{array}$ & $\begin{array}{l}\text { gyógytornász, } \\
\text { szomatopedagógus } \\
+ \\
\text { hippoterapeuta } \\
\text { végzettség }\end{array}$ & $\begin{array}{l}\text { gyógypedagógus } \\
+ \\
\text { lovasterapeuta } \\
\text { végzettség }\end{array}$ & $\begin{array}{l}\text { pszichológus } \\
+ \\
\text { lovas pszichoterapeuta } \\
\text { végzettség }\end{array}$ \\
\hline Terápia típusa & neurofiziológiai & fejlesztő, nevelő & $\begin{array}{lr}\text { lóval való foglalkozás } \\
\text { pszichés } & \text { hatásait } \\
\text { alkalmazza } & \end{array}$ \\
\hline $\begin{array}{l}\text { Terápián résztvevők } \\
\text { száma }\end{array}$ & egyéni & egyéni/csoportos & egyéni/csoportos \\
\hline
\end{tabular}




\begin{tabular}{|c|c|c|c|}
\hline $\begin{array}{l}\text { Alkalmazási } \\
\text { területek }\end{array}$ & $\begin{array}{l}\text { mozgás funkciók } \\
\text { javítása, korrekciója } \\
\text { ortopédiai problémák }\end{array}$ & $\begin{array}{l}\text { értelmileg } \\
\text { akadályozott, } \\
\text { tanulásban } \\
\text { akadályozott, autista, } \\
\text { hiperaktív, látás és } \\
\text { hallássérült, } \\
\text { részképességzavaros, } \\
\text { magatartászavaros } \\
\text { személyek }\end{array}$ & \begin{tabular}{lr} 
legtöbb & \multicolumn{2}{c}{ pszichiátriai } \\
betegség, affektív és \\
depresszív kórképek, \\
szorongásos zavarok, \\
személyiség- \\
viselkedészavarok, és \\
szenvedélybetegségek
\end{tabular} \\
\hline Terápiás jármódok & lépés & lépés, ügetés, vágta & lépés, ügetés, vágta \\
\hline
\end{tabular}

A pszichés fejlesztés mindig hozzájárul a különböző területek fejlesztésének sikerességéhez, üteméhez. Az értelmi fejlesztés, a tudás átadása is mindig fejlesztő hatással bír és a lovaktól, illetve a lovakról is rengeteget tanulhatunk. [6]

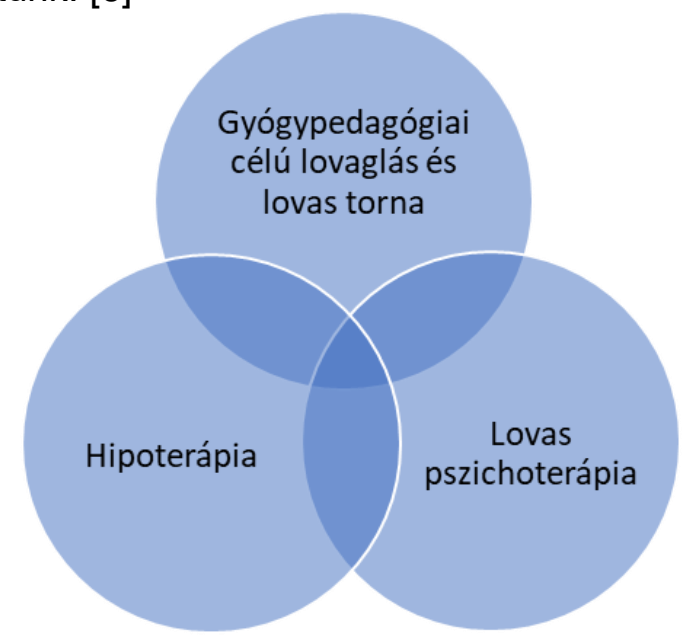

3. ábra: A lovasterápia 3 területének részmetszeti rajza. (Készült: „Hasonlóságok a lovasterápiában" c. ábra alapján [1])

\subsection{A ló, mint társ és a lovasterápia alapja}

„A lóban megtestesülő (...) személyiségbeli jellemzők azonosak az emberben megtestesültekkel. (...) Talán a lovak megértése iránti vágyunk nem is más, mint magunk és környezetünk megértésének szándéka" [7].

A ló, mint társ és aktív résztvevő vesz részt a foglalkozásokon, ezáltal fontos a ló és ember között megjelenő kapcsolat, illetve, hogy a ló alkalmas legyen a lovaglásra. Carl Klüver már 1994ben megjelent elmélete [8] tárgyalja ennek a különleges kapcsolatnak az egyik alappillérét, az ősi bizalmat. Az elmélet lényege, hogy kb. 3,9 milliárd évvel ezelött, a Földön kialakultak az evolúció során olyan anatómiai és élettani egyezések, homológiák az élölények között, amelyek például a lovakban és az emberekben is megtalálhatóak. Ezek azok a hasonlóságok, amelyek megalapozzák a terápiás munkát [9]. A bizalom nagyon fontos a terápia során, melynek alapja a rokonságon alapuló önkéntelen érzelmek [1]. Az ember bizalma abban mutatkozik meg, hogy a méret, a felmerülő problémák (lábra lépés, rúgás, harapás) ellenére is megállunk előttük, megsimogatjuk, megöleljük. A ló csoportban élő menekülö állat, ezáltal a ló bizalma már abban is fellelhető, hogy magához közel enged minket. Fontos kiemelnünk, hogy abból adódóan, hogy a lovak csoportban élő állatok a bizalom mellett fontos a terapeuta tekintélye a ló számára, ezáltal lesz a bizalom kölcsönös. Ebböl következik, hogy a lovakat csak megfelelö képzés, illetve vizsgáztatás után tudjuk terápiás célra használni. A lovak folyamatos képzése, illetve az aktív és passzív pihenés biztosítása számukra a terápiás foglalkozások során nélkülözhetetlen.

A lovaknak a belső és külső tulajdonságaik is hozzájárulnak a fejlesztés sikerességéhez. A belső tulajdonságok közé soroljuk, hogy: 
- szelídíthetők,

- csoportban élö állatok,

- házasíthatók,

- együttmüködési készséggel rendelkeznek,

- engedelmesek,

- temperamentumuk is megfelelö lehet.

A szelídíthetőség alatt értjük mindazt, hogy a ló képezhető, fejleszthető, tanítható. A csoportban élés által a lovak kapcsolatot alakítanak ki egymás között, de hasonló kapcsolatot képesek emberrel is kialakítani. Sokszor megfigyelhető az egyedül tartott lovaknál, hogy gazdájukat hanggal keresik, gazdájuk szavaira válasz hangokat adnak. A legtöbb ló nagyon jól tud alkalmazkodni, jól kompenzálnak. Az engedelmesség az egyik legnagyobb tükre az ember és ló között kialakult bizalomra és tekintélyre. Ha a bizalom és a tekintély nem megfelelő a ló és az ember között, akkor az engedelmességben már felmerülő problémákkal találkozhatunk, ezért kiemelendő a folyamatos képzésük. A lovak temperamentuma sokban hozzájárul ahhoz, hogy az adott ló alkalmas-e a terápiás foglalkozásokra. Fontos tulajdonságuk a lovaknak, hogy nem ítélik meg az ember viselkedését, gondolatait, cselekedeteit, érzelmeit, hanem egyenesen reagálnak rájuk, őszinte és ítélet nélküli reflexiót adnak a lovasnak [4]

A lovaknál is, mint az embereknél vannak különböző típusok. Vannak olyan fajták, melyek genetikájukból, illetve idegrendszeri alapon olyan temperamentummal rendelkeznek, hogy nem alkalmasak terápiás lónak.

A külső tulajdonságok közé sorolhatjuk:

- méretüket,

- teherbírásukat,

- külső megjelenésüket,

- testhömérsékletüket,

- mozgásfolyamatukat.

A lovak mérete és teherbírása meghatározó abban, hogyan lovagolható, habár a megfelelö méretet meghatározzák az egyén igényei is: minél kisebb egy ló, annál gyorsabban lép a rövidebb lépéstávolság miatt, ezáltal a lovasra gyakorolt rezgések is sürübbek. A hosszabb lépések nyugtatólag hatnak, addig a rövidebb lépések fokozhatják az arousal szintet [4]. A lovak testhőmérséklete az emberénél magasabb $38^{\circ} \mathrm{C}$. Ez az az úgynevezett melegség, mely a lovakból árad fizikálisan is tapasztalható, megélhető: fontos része a terápiának.

A lovak mozgásfolyamata is nagyban hozzájárul a terápiához, ezáltal fontos, hogy ez a mozgásfolyamat ép és egészséges legyen (4.ábra).

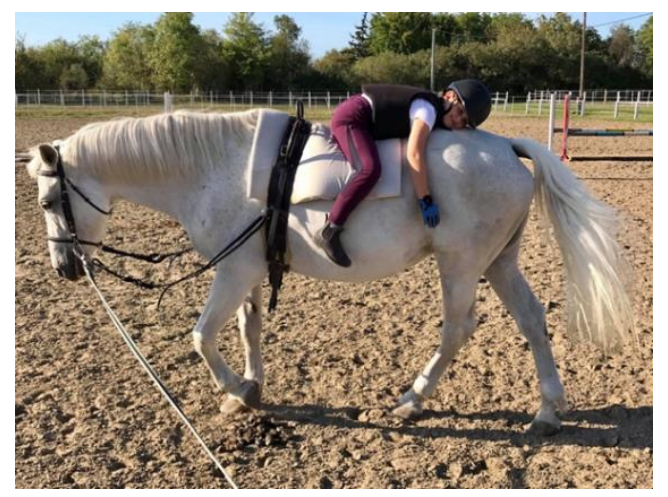

4. ábra A ló nyugtató, ringató hatása a lovasra.

\subsection{A ló mozgása}

A ló mozgása különösen fontos a lovaglás során. Ismernünk kell a ló mozgását ahhoz, hogy megfelelően, alkalmazkodni tudjunk hozzá lovagláskor, illetve gyógylovaglás során a ló mozgását is alkalmazni tudjuk a sikeres fejlesztéshez.

A ló előre haladása, annak lendülete a hátsó lábakból ered, ahogy a laikusoknak elmagyarázzák: „hátsó kerék meghajtású”. A hátsó lábak mozgása eredményezi a ló csípőjének, 
illetve azon keresztül a ló hátának a mozgását [10]. A ló elöre lendíti az egyik hátsó lábát, míg a másik hátsó lábán (melyen ekkor a ló testsúlya van) támaszkodik majd, amikor az előre lendített hátsó lábát a talajra helyezi a ló, a testsúlyát áthelyezi arra a lábára és lendíti a másik hátsó lábát elöre [11]. A hátsó lábak mozgásából következik a ló csípőjének mozgása, mindig az az oldala emelkedik meg a csípőjének, amelyik hátsó lába éppen a talajon van (fontos: ezen helyezkedik el ekkor az állat testsúlyának egy része). A csípő a keresztcsonton keresztül kapcsolódik a ló gerincoszlopához, ezáltal a hátsó lábak mozgásának hatása kihat a ló hátára. A hátsó láb mozgása által a csípőben kialakult fel-le mozgás a keresztcsontra vezetődik, és azt fél ütemben mozgatja. Minden egyes lépés során a hát jellemzően fel és le mozog, ami az egymást követő bal és jobb végtagok lépéseinél két fel és le mozgást jelent, tehát a jelben két csúcs és két vályú van, amint az az 5. ábrán látható.

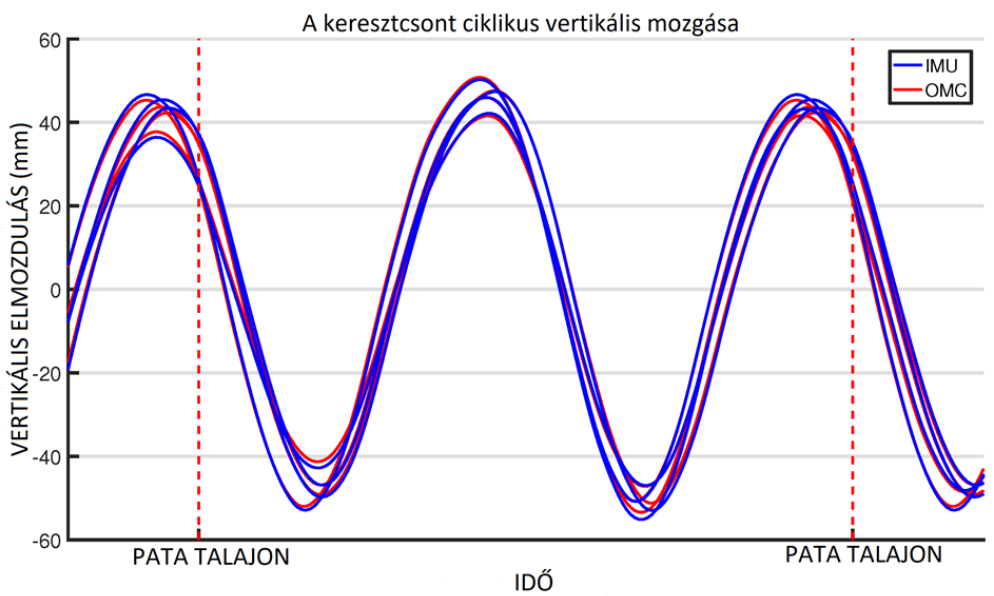

5. ábra A keresztcsont ciklikus vertikális mozgásának diagramja IMU (Inertial Measurement Unit) és OMC (Optical Motion Capture) eszközökkel rögzítve. [12]

Terápiás szempontból a ló három jármódja lényeges (6. ábra), ez a lépés, ügetés és a vágta. Mindhárom jármódban a ló más lábsorrenddel és más ütemben halad elöre.

A lépés 4 ütemű mozgás, mely során a lábsorrend a következő: 1. jobb hátsó láb, 2. jobb első láb, 3. bal hátsó láb, 4. bal első láb. Az ügetés 2 ütemü, melyben ló egyszerre két lábát lendíti, ebböl adódik, hogy egy ütem alatt két láb mozog. A lábsorrend a következő: 1. jobb hátsó-bal első, 2. bal hátsó-jobb első. A vágta 3 ütemü, legtermészetesebb és leggyorsabb jármód. Szemben a többi mozgásformával, ahol mindig legalább egy végtag a talajon van, itt beszélhetünk úgynevezett lebegő fázisról, amikor is egy végtag sem éri a talajt. Vágtában a ló lábsorrendjét meghatározza, hogy melyik irányba vágtázik [13]. Jobbra vágta esetén a lábsorrend: 1.bal hátsó láb: elrugaszkodás, 2. jobb hátsó láb-bal első láb, 3. jobb első láb: hosszan elöre nyúlik. Balra vágta esetén a lábsorrend: 1. jobb hátsó láb: elrugaszkodás, 2. bal hátsó láb-jobb első láb, 3. bal első láb: hosszan elöre nyúlik.

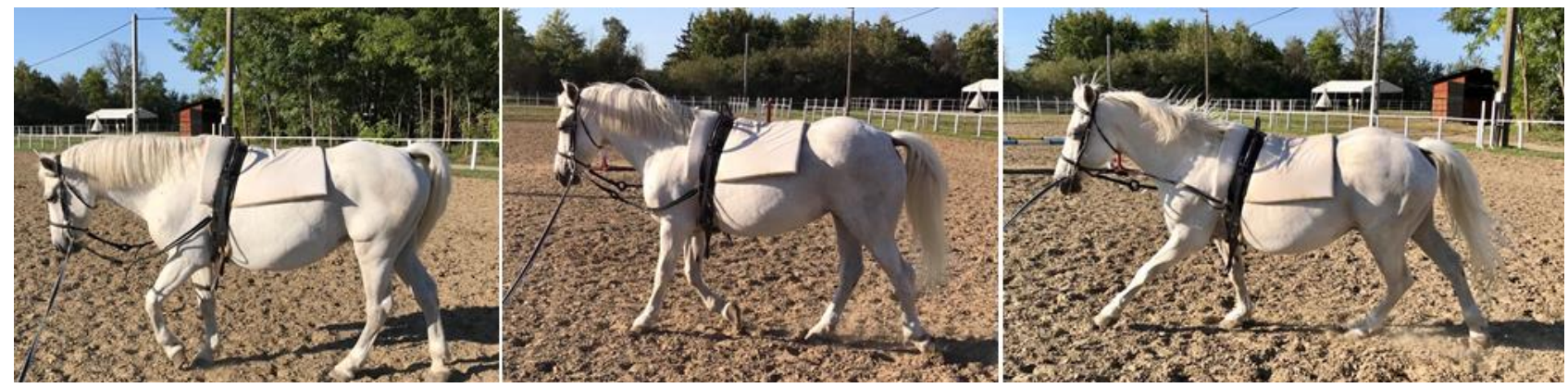

6. ábra: A ló mozgása és lábsorrendje lépés, ügetés és vágta közben. 


\section{Lovaglás a gyógypedagógiában}

Ebben a gyógypedagógiai lovaglás és lovastorna területre fókuszálva, a terápiának a lovaglás oldalát közelítjük meg. A lovas passzívan is követi a ló mozgását, mozog a ló által létrehozott hatások következtében, ezáltal a ló mozgásának eredményeképp a lovas mozgása háromdimenzióssá válik: a háton keresztül, elsősorban az alátámasztási pontokon a lovasra vezetett mechanizmusok által a lovas mozog fel-le, jobbra-balra, és megfigyelhető egy elöre ringató mozgás is. A fel-le mozgás és a jobbra-balra mozgás a testsúly egyik hátsó lábról a másik hátsó lábra helyezés által alakul ki, mivel a ló csípője felemelkedik, majd süllyed. Amikor a lovas jobb oldala emelkedik meg a lovon, a ló éppen a jobb hátsó lábán lép, amikor a bal oldala emelkedik meg a lovasnak, akkor a ló a bal hátsó lábán lép éppen. A ló kb. 90-110-et lép egy perc alatt, így egy 30 perces fejlesztés során 3000 fiziológiás impulzust közvetíthet a lovas felé $[2,4]$.

A terápia lényege is az, hogy a lovas aktívan és passzívan követi a ló mozgását. Az egyik legfontosabb tényező, hogy a lovas hagyja, hogy vigye a ló és ezáltal a ló önkéntelenül is átmozgatja a lovas testét [1]. A ló mozgása és jármódja hatással van a lovasra. A lovas 3 fő ponton érintkezik a lóval: az ülőgumó, a combok és a lábszárak. A ló mozgása ezen pontokon keresztül több erővel hat a lovasra: a lengésimpulzus mely a hát fel-le mozgásából adódik, a gyorsulásierő ami a hátsó lábak toló erejéből származik és a centrifugális erő. Az említett ingerek által olyan érzékszervek és idegi pályák jönnek müködésbe a lovas hátán továbbvezetett rezgések által, amelyek a mozgásemlékezetért (piramidális és extrapiramidális pályák) felelősek. „Amennyiben egy gyermeknél koraszülés következtében ezeknek az érzéki tapasztalatoknak a folyamata megszakadt, a lovasterápia azokat pótolhatja, helyettesítheti. Fejleszti az idegösszeköttetéseket, vagy akár új idegmüködéseket is beindíthat" [14]. Ebből adódik a következő területek sikeres fejleszthetösége:

- egyensúlyérzékelés

- koordináció

- érzékelés

- tartás

- járás

Carl Klüver 1987-ben [1] megfogalmazta az alkalmazási és hatásterületeket

A ló mozgása által létrejövő háromdimenziós lengés. A lovagláskor létrejövő impulzusok, rezgések által lehetőség nyílik a kisagyban újabb idegi utak kiépítésére, gyakorlatoztatására. $A$ kialakítható új idegi utak lehetőséget adnak olyan mozgásfolyamatok számára, amelyek sérülés vagy megbetegedés miatt nem müködnek. A lovasterápia az agy és a gerincvelő motoros és szenzoros területeire, valamint az ehhez tartozó szállítószövetekre gyakorolt hatását semmilyen más természetes módszerrel, géppel vagy szerkezettel nem lehet a valóságnak megfelelően utánozni. Ezért a ló a maga tulajdonságival egyedülálló lehetőséget nyújt ahhoz, hogy terápiás módszerrel egyészségjavító mozgásterápiát végezzünk [1].

A válaszviselkedés a ló egyensúlyán keresztül. A ló, teherbírása által a lovas összsúlyára kiegyensúlyozó magatartással reagál. A ló hátának lengései az alátámasztási pontok által továbbvezetett mozgásokon keresztül passzívan a lovast folyamatosan arra készteti, hogy önmagát egyensúlyban tartsa. A lovas a stabil helyzet kialakítására törekszik az izmai elernyesztésével és megfeszítésével. A ló lépésben haladása során a tartó-kiegyensúlyozó munkája segíti a lovast az egyensúly megtalálására és megtartására.

A mozgásdialógus és pregesztikus viselkedés az utasítások összehangolásán keresztül. Lovaglás során a ló és lovas folyamatosan kommunikálnak egymással a lovas testsúlyával, a három alátámasztási ponton, a szársegítséggel és a ló megértése által, ezáltal jön létre a ló irányítása, sebességének szabályozása is.

A csoportban való fajspecifikus viselkedés, a szociális tanulás eredeti formája. A gyógypedagógiai lovaglás és lovastorna résztvevője a ló. A ló tükröt tart a lovasnak és a csoportnak is azáltal, hogy a ló képes felvenni a csoport hangulatát és ezt képes kifejezni a lovasnak, csoportnak. 


\section{Gyógypedagógia a lovaglásban}

Gordosné [15] megfogalmazása szerint a gyógypedagógia fogalomnak két értelmezése van, egy tágabb és egy szükebb. A szükebb értelmezés fogalma szerint a „speciális nevelési segítséget igénylők nevelési tudománya: a gyógyító nevelés lehetőségeit, elv- és feltételrendszerét, múltját, cél-, feladat-, eszköz-, szintérrendszerét és eredményességét vizsgálja optimális szocializációjuk és sikeres rehabilitációjuk szolgálatában. Ágai a tovább differenciálódott speciális pedagógiák, az általános gyógypedagógiai diszciplínák” [15]. „A tágabb értelemben vett gyógypedagógia viszont a speciális segítséget igénylökkel összefüggő teljes jelentéskört kutatja: a serülés kóreredetét, kóros mechanizmusait, a sérülések fejlődésmenetét, személyiségszerkezetét, pszichés funkcióit, társas környezetét, és kapcsolatait, rehabilitációjuk lehetőségeit, kilátásait" [15].

A gyógypedagógiai lovaglás és lovastorna fejlesztési lehetőségei sokoldalúak, melyet a lovas egyéni igényei, problémái, összhangban a terápiás célokkal és fejlesztési területekkel együttesen határoznak meg [16]. A foglalkozás lehet egyéni, illetve csoportos. Az egyéni fejlesztés még tovább bontható vezetett lovon történő fejlesztésre, futószáron történő lovagoltatásra és önálló lovagoltatásra (11. ábra) [16].
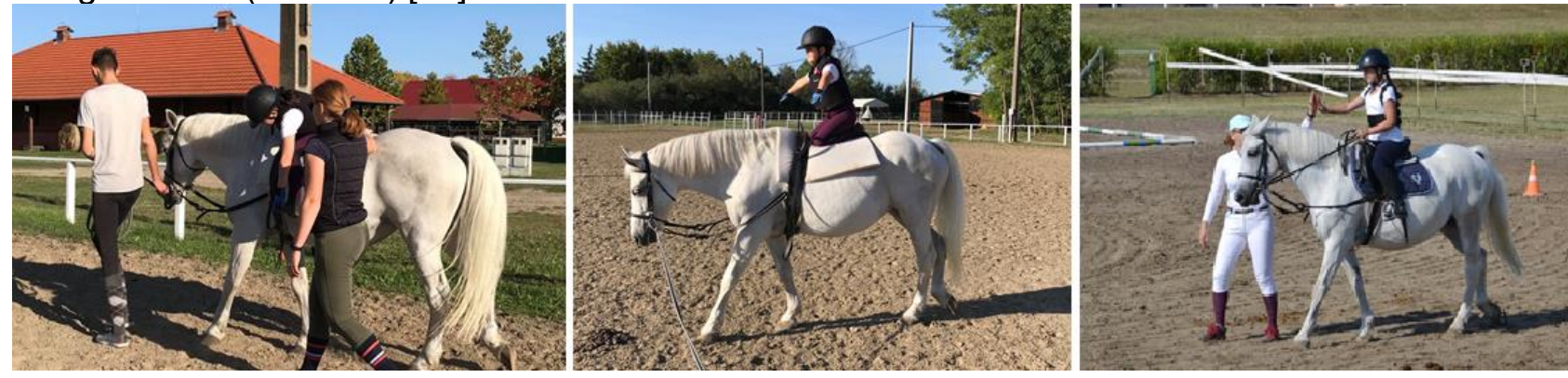

11. ábra: Lovas foglalkozások vezetett lovon, futószáron és önállóan.

A gyógypedagógiai lovaglás és lovastorna egyéni, vezetett lovon történő fejlesztés során egy különleges kapcsolat alakul ki a résztvevők között. A központi résztvevő maga a lovas és a lova. A lóvezető irányítja és segíti a lovat, a terapeuta kéréseire, a fejlesztési célnak megfelelően. A terapeuta feladata komplex: a lovas segítése és fejlesztése az elsődleges. Közvetett feladatként ki kell emelni a ló megfelelő háttérképzését és képzettségének fenntartását biztosító eljárásokat, illetve azokat a kéréseket melyeket a lovasterapeuta megfogalmaz és a lóvezető visz véghez (7. ábra).

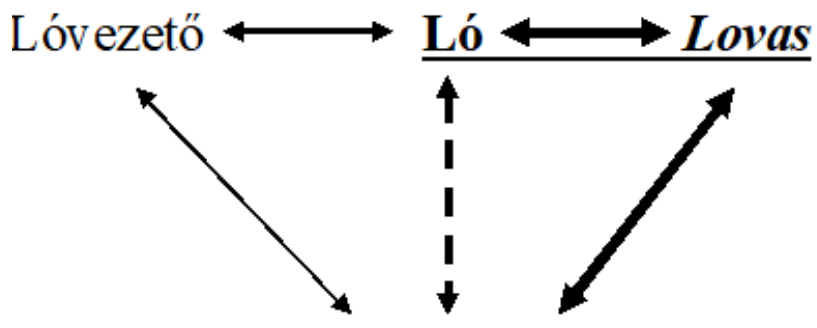

Terapeuta

10. ábra Ló, lovas, lóvezető, terapeuta kapcsolata a vezetett lovon történő fejlesztés során.

A terapeuta közvetlenül is kapcsolatban áll a lóval, a terápia folyamán megjelenik a taktilitás (pl.: „Simogassuk meg együtt a nyakát!”) és a szóbeli kommunikáció is (pl.: „Dicsérjük meg együtt a lovunkat!") A Ló és lovas kapcsolat a legfontosabb a terápia során, mely megvalósul fizikálisan és pszichésen és a mozgásos folyamatokban is, melyekről az előző bekezdésekben részletesebben is olvashattunk. A lovaglás voltige hevederben történik.

A gyógypedagógiai lovaglás és lovastorna során két terület rajzolódik ki, mivel minden értelmi fejlesztés alapja a mozgásfejlesztés, ezért alkalmazzuk a mozgásfejlesztés elemeit és erre alapozva a különböző gyógypedagógiai fejlesztésben is alkalmazható fejlesztő eszközöket, játékokat konvertálunk át lóra. A lovas mozgását a gimnasztika különböző gyakorlataival és a lovastorna 
elemeivel, a ló mozgásának segítségével is fejleszthetjük. A felsorolt feladatokat színesebbé tehetjük játékos körülmények között labdával, mondókával, különböző játékokkal, mint pl.: vállkörzés: elöre-hátra, karkörzés: egyesével, párosával, malomkörzéssel, elöre-hátra), törzsfordítások: jobbra-balra, törzsdöntések: azonos-ellentétes oldali cipő megérintése.

A lovastorna gyakorlatai által fejlődik [8] a lovas szem-kéz koordinációja, a koncentrációja, a testsémája, az önbizalma, az észlelése (pl.: mélyészlelés) A lovastorna elemei közé sorolhatjuk pl.: malom, térdelés, guggolás, majomállás, szék, asztal, törökülés stb..

A lovastorna elemei végezhetők egyénileg, párosával, illetve csoportban is. Azon szociomotorikus gyakorlatok, melyeket csoportban is alkalmazhatunk, elösegítik a kommunikációt a lovasok között, a sikeres feladatvégrehajtás elérése érdekében, melynek alapja a korlátozott és mozgó helyen végzett gyakorlatok: a csoportban végzett lovastorna elemeinek lényege, hogy a résztvevők képesek legyenek a rendelkezésükre álló szük teret úgy elosztani, hogy mindenkinek jusson.

A lovon használt eszközök, játékok alkalmazásának célja a lovas megfelelő fejlesztése a motiváció fenntartásával. A lóvezető szerepe ezért is kiemelt fontosságú, a terapeuta a fejlesztő eszközt, játékot be tudja mutatni a lovasnak, a feladat végrehajtását képes felügyelni, segíteni és végül értékelni. Különböző eszközök bevonásával azonban időközben még további lehetőségeink adódnak pl. a kognitív funkciók (érzékelés, észlelés, emlékezet, figyelem, gondolkodás), a beszédfejlesztés, a motoros és orientációs képességek, az érzelmi állapot, az akarati cselekvések befolyásolása, a szocializáció elősegítése stb. érdekében [8].

Fejlesztő eszköz, játék pl.: csipesz, báb, kugli, labda, buborékfújó, különböző kártyák, gyöngyök, kirakók, karikák, babzsák.
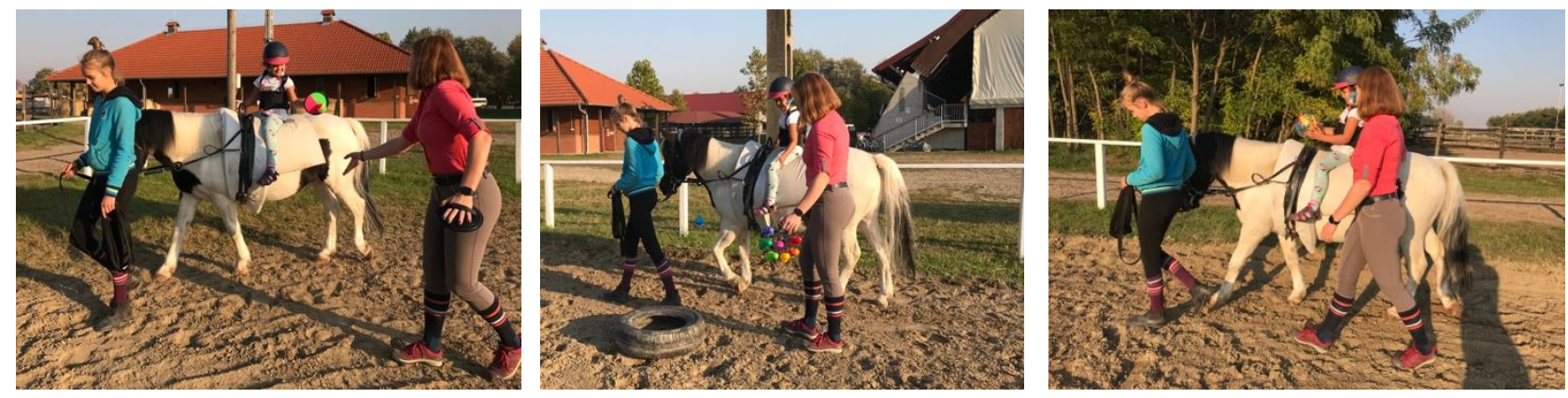

11. ábra Fejlesztő eszközök, játékok alkalmazása vezetett lovon történő

fejlesztés során.

\section{5. Összegzés és jövőkép}

A gyógylovaglás komplexitása és sokszínü alkalmazási lehetősége vitathatatlan. A ló nem elhanyagolható a terápia során, mivel fontos társként funkcionál a fejlesztések során. Fontos kiemelni, hogy a lovasterápia végzésére csak a megfelelő kompetenciával rendelkező szakemberek jogosultak. A lovaglás és a gyógypedagógia fejlesztő hatásai kölcsönhatásban vannak és kiegészítik egymást. A ló, mint élölény, mint állat és mint társ, illetve a mozgásából származó impulzusok lovasra gyakorolt hatásai motivációt, nyugalmat, kapcsolatot és a különbözö területek sikeres fejleszthetőségét eredményezi. A gyógypedagógia kreativitása, rugalmassága pedig lehetővé teszi, hogy egy sokoldalú, élvezetes és színes fejlesztésben vehessenek részt a lovasok. A lovaglás fejlesztő hatásai, illetve a gyógypedagógia fejlesztő tevékenységei egyaránt érvényesülnek a terápia során, valamint fontos a terápiában résztvevők, közremüködők között kialakuló kapcsolat, a hatásokban így az objektív és szubjektív tényezők összefonódnak [15].

Magyarországon is egyre keresettebbek a lovasterápiás fejlesztések, viszont hiányosak a fejlesztés sikerességét igazoló számadatokat egyértelműen tartalmazó publikációk, melyek szükségesek ahhoz, hogy a lovasterápiás képzés didaktikailag fejlödjön, illetve a pedagógián túl, a medicina is elfogadja, mint effektív terápiás eszközt. További kutatási cél, hogy bebizonyíthassam tudományos igény szintjén, a lovasterápiás foglalkozások igenis sikeresek, fontosak és 
szükségesek, a terápiával mérhető és értékelhető változást lehet elérni. A kutatásom módszertanában kiemelt szerepet kap a széles körü, megfelelő számú lovas bevonásával történő vizsgálat. A kutatás további célja, hogy a lovasterápia hasznossága a lehető legnagyobb mértékben objektív bizonyítást nyerjen, ezáltal a gyógypedagógiai lovasterápia sikeressége is minél inkább szakmailag alátámasztott, megkérdőjelezhetetlen lehessen.

\section{Irodalomjegyzék}

[1] Wipke C. Hartje (2012): Lovasterápia: gyógypedagógiai lovaglás, lovas pszichoterápia. Mezőgazda, Budapest.

[2] Györgypál Zoltánné (2007): Hippoterápia. Unicornis Egészségmegörző Alapítvány. http:// www.unicornis97.hu/index.php?action=lova sterapia\&command=hippoterapia

[3] Topár Zsolt (2007): Lovasterápia. Csengő parasport lovas szakosztály. http://csengolovas.hu [Utolsó megtekintés: 2019.10.02.]

[4] Bozori Gabriella (2002): Lovasterápia - gondolatok vázlatok a gyógypedagógiai lovaglás és lovastorna témaköréből. Polu-Press Kft., Székesfehérvár.

[5] Füléné Horesnyi Zsuzsanna (2010). Lovasterápia. Táltoslépcső képességfejlesztés és oktatás. http://szegedkineziologia.hu/lovas_terapia.php

[6] Hevesi Tímea (2013): Tudásbővítés, fogalomelsajátítás in: Köböl E., Hevesi T., Topál J.: Állatasszisztált foglalkozások http://www.jgypk.hu/mentorhalo/tananyag/Allatasszisztalt_foglalkozasV2/2112_tudsbvts_fogalomtanuls.html [utolsó megtekintés: 2019.10.02.]

[7] Miller, M. (2012). Értsük meg a ló viselkedését! Budapest: Mezőgazda Kiadó.

[8] Schéder Veronika (2017): Lovasterápia, A neuro- és pszicholingvisztikai zavarok rehabilitációjában. Nyíregyháza.

[9] Schéder Veronika (2015): Különleges bánásmód ló-asszisztált foglakozásokon. Különleges Bánásmód I. évf 2015/1. szám 79-89

[10] M. Düe, K. Miesner, S. Miesner, M. Plewa, M. Putz, C. Veltjens-Otto_Erley (2005): A jól képzett ló, Mezőgazda Kiadó, Budapest

[11] Pálinkás Judit, Manó Sándor, Soha Ferenc Rudolf, T. Nagy Judit (2016): A ló egy lépésciklusának nyolc periódusú képi megjelenítése és a marmozgások kétdimenziós gyorsulásaival való szinkronizálása, Biomechanica Hungarica 9.(1.) http://biomechanica.hu/index.php/biomech/article/viewFile/222/340 [Utolsó megtekintés: 2019.10.02.]

[12] Bosch, S., Serra Bragança, F., Marin-Perianu, M., Marin-Perianu, R., van der Zwaag, B., Voskamp, J., ... \& Havinga, P. (2018). EquiMoves: a wireless networked inertial measurement system for objective examination of horse gait. Sensors, 18(3), 850. https://www.mdpi.com/14248220/18/3/850/htm?fbclid=IwAR1c2PJYTfYKOTI3Lzj9SFB_5IxI_IsAcXphrP-I9FP2Zfw83CXrkWv0_SQ [utolsó megtekintés: 2019.09.25.]

[13] Reiner Klimke (1990): Fiatal hátasló alapkiképzése, Mezőgazda Kiadó, Budapest

[14] Büki Görgy (2006): A hippoterápia neurofizikai alapjai in: Schéder Veronika (2017): Különleges bánásmód lóasszisztált foglakozásokon. Különleges Bánásmód I. évf 2015/1. szám 79-89

[15] Gordosné Szabó Anna (2004): A hagyományit megőrizve megújult a magyar gyógypedagógiai tevékenység In: Gordosné: Gyógyító pedagógia - Nevelés és terápia. Medicina, Bp., p. 11-18

[16] Bozori Gabriella (2011): A gyógypedagógiai lovaglás és lovastorna, mint a gyógypedagógiai terápiák egyfajta lehetősége. Budapest 